DOI https://doi.org/10.30525/978-9934-26-038-4-49

\title{
MUCOSAL LYMPHATIC NODULES OF RATS WITH SKIN EXPERIMENTAL BURN TRAUMA UNDER THE ACTION OF HECOTON SOLUTION
}

\section{Sokurenko L. M.}

Doctor of Medical Sciences, Professor, Professor at the Department of Histology and Embryology

Bogomolets National Medical University

Educational and Scientific Center "Institute of Biology and Medicine»

of Taras Shevchenko National University of Kyiv

Kyiv, Ukraine

\section{Matkivska R. M.}

Candidate of Medical Sciences, Associate Professor, Associate Professor at the Department of Descriptive and Clinical Anatomy

Bogomolets National Medical University

Kyiv, Ukraine

\section{Yaremenko L. M.}

Doctor of Medical Sciences, Professor, Professor at the Department of Histology and Embryology

Bogomolets National Medical University, Kyiv, Ukraine,

\section{Kaminsky R. F.}

Candidate of Medical Sciences, Associate Professor, Associate Professor at the Department of Descriptive and Clinical Anatomy Bogomolets National Medical University

Kyiv, Ukraine

\section{Prysiazhniuk L. V.}

Assistant Professor at the Department of Descriptive and Clinical Anatomy Bogomolets National Medical University

Kyiv, Ukraine

Introduction. Intestinal mucosal barrier is formed by intestinal epithelial cells and intestinal intraepithelial lymphocytes that reside between them [1]. Mucosal lymphatic nodules (Peyer's patches) associated with mucous 
membranes form a protective barrier against antigens. The function of Peyer's patches involves recognition luminal antigens, inducing an immunological response and decreasing the incidence of antigen translocation across the mucosal epithelium [2].

That is why it is interesting to study their reactive changes in such a multiorgan disease as burn disease, which is affected many factors such as oxygenation, infection, aging, hormones, and nutrition [3].

The aim of the work. Microscopic and ultramicroscopic study of the ileum lymphoid nodules (Peyer's patches) structure of rats with burn disease and infusion of hecoton solution.

Materials and methods. Experimental animals were divided into 3 groups (18 animals in each group): I - intact animals; rats of groups I and II were infused with a solution of a new hyperosmolar drug «Hecaton», which was registered in Ukraine in 2013 (Certificate NUA/13224/01/01), at a dose of $10 \mathrm{ml} / \mathrm{kg}$. Animals of group II - without experimental burn skin injury, III - with experimental burn skin injury. The solutions were infused for 5 minutes into the caudal vena cava after catheterization under aseptic conditions through the femoral vein. The first infusion was performed 1 hour after the application of the experimental burn injury of the skin, subsequent injections were performed once a day for the first 7 days of the experiment. Material was collected from rats under deep thiopental intraperitoneal anesthesia $1,3,7,14,21$ and 30 days after experimental skin burn injury. The structure of lymphoid nodules of the ileum (Peyer's patches) was studied histologically (stained with hematoxylin-eosin with subsequent examination under an Olympus BX51 microscope) and electron microscopically methods (fixation in a solution of glutaraldehyde in the production of semi-thin and ultrathin sections on an ultramicrotome LKB-3 (Sweden)) with subsequent study on an electron microscope PEM-125K) [4].

Research results. Compensatory-adaptive effects of hecoton intravenous infusion on the experimental burned animals ileum lymphoid nodules structure are characterized by inhibition of normal structure lymphocytes and apoptotic lymphocytes necrosis. Infusion of Hecaton solution helps to preserve the normal structure of the nodular lymphatic capillaries.

Apoptotic clearance is normalized. There is a structural preservation (and increase in structural resistance) of dendritic cells and macrophages, which allows the normal course of antigen-presenting and phagocytic function. The observed changes in lymphocytes are a manifestation of their stress response to burns, which consists of initial adequate damaged lymphocytes apoptotic elimination, subsequent regenerative proliferation program energy supply disruption or adaptive response failure - in chaotic and asynchronous apoptotic and preserved cells necrotic destruction. 
There is also a tendency to wavy changes in the average cross-sectional area of blood capillaries in ileum lymphoid nodules clusters of rats with experimental burn skin trauma. The cross-sectional area of blood capillaries increased statistically significantly, respectively $16,0 \%$ i $12,0 \%(p<0,05)$.

Conclusions. Thus, the results of our study indicate that Hecaton solution infusion compensated for the detected alteration manifestations with experimental skin burn trauma. It is carried out by protecting cells from damage that leads to cell death; by increasing the intact cells proliferation; andalso involving additional mechanisms that change the conditions and rate of immunocompetent cells recirculation. Our results indicate an integrated response of the immune system to burns, which can be optimized and stabilized with timely and adequate infusion therapy.

\section{References:}

1. Olivares-Villagómez D, Van Kaer L. Intestinal Intraepithelial Lymphocytes: Sentinels of the Mucosal Barrier. Trends Immunol. 2018. Apr; 39(4): 264-275. doi: 10.1016/j.it.2017.11.003. Epub 2017 Dec 5. PMID: 29221933.

2. Heel KA, McCauley RD, Papadimitriou JM, Hall JC. Review: Peyer's patches. J Gastroenterol Hepatol. 1997 Feb; 12(2): 122-36. doi: 10.1111/j.1440-1746.1997.tb00395.x. PMID: 9083913.

3. Roshangar L, Soleimani Rad J, Kheirjou R, Reza Ranjkesh M, Ferdowsi Khosroshahi A. Skin Burns: Review of Molecular Mechanisms and Therapeutic Approaches. Wounds. 2019 Dec; 31(12): 308-315. Epub 2019 Sep 30. PMID: 31730513.

4. Черкасов В.Г., Дзевульська I.В., Камінський Р.Ф., Матківська Р.М., Гамалій В.М., Сокуренко Л.М. Морфологічні зміни лімфоїдних вузликів клубової кишки щурів з експериментальною опіковою травмою шкіри за дії лактопротеїну з сорбітолом Сучасні проблеми морфології людини: зб. тез доп. Всеукр. наук.-практ. конф. 3 міжнар. участю (м. Харків, 23-25 вересня 2020 р.). - Харків: ХНМУ, 2020. C. 41-43. 